$\mathrm{C},[\alpha]_{\mathrm{D}}^{26}=-17.6^{\circ}(c=0.35$, エタノール $)$

分析值 C $59.6 \%, \mathrm{H} 7.15 \%, \mathrm{~N} 4.05 \%$

$\mathrm{C}_{18} \mathrm{H}_{23} \mathrm{O}_{4} \mathrm{~N} \cdot \mathrm{HCl}$ としての

計算值 C $61.1 \%, \mathrm{H} 7.05 \%, \mathrm{~N} 3.95 \%$
終りに，原料の D-グルコサミンを御恵与下さった 奈良女子大 学松島祥夫教授，分析をして下さった当教室分析室のかたがたに 深く感謝します。

（第 3 報） $\quad \beta-1-C$-フェニル-2-アセトアミノ-2-デオキシ-3, 4, 6-トリアセチル-D-

グルコピラノシドの異常核置換反応および $\boldsymbol{\beta}-1-C_{-}(\boldsymbol{p}-$ ニトロフェニル $)-2-$

ジクロルアセトアミノ-2-デオキシ-D-グルコピラノシドの合成について

（吉村 寿次・中川 淑郎・佐藤 徹雄）

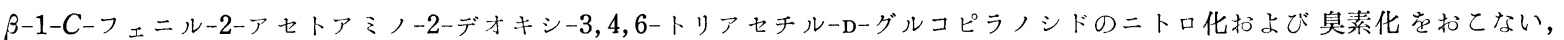
それぞれ $p$-ニト口 (V) 打上び $m$-二ト口誘導休と $p$-ブロム誘導体を純䊉な結晶として得た。 $m$-二ト口誘導体が生成す为異常反 応について検討した。V党酸で脱アセチルし，ついで $N$-シシクロルアセチル化して，一種のクロラムフェニコール誘尊体と考光ら

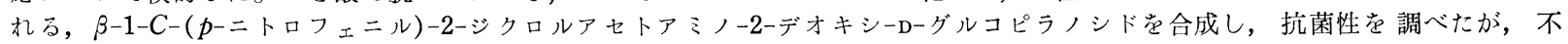
活性であった。

\section{1 緒論}

さきに Bonner ら1は親水性で，安定で，かつ比較的大きな侧 鎖を持ったベンゼン褋導体と考えられる $\beta-1-C-フ ェ ニ ル-2,3$, 4,6-テトラアセチル-D-グルコピラノシド（Ｉ）の核置換反忘， すなわちニトロ化拉よび具秦化について研究を行ない，つぎのこ

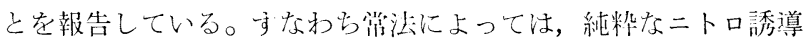
体をうることができないが，䣷酸と無水酭酸の混液中で硄酸銅と 加熱することにより $p^{-}$ニト口唀導体（II） と，o- および $p$-二 ト口誘導体の混合物であると沶もわれるシロップが得られる。ま た臭素化では相当するフェニルグルコシドと異なり2)臭素のみで は反応しないが，㙉化第二鉄を触媒として用いると，3,4-ジブロ ム誘導体 $(\mathbb{I I})$ と， III拉よび $p$-ブロム誘導体の混合物が得られ る。

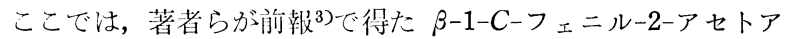
ミノ-2-デオキシ-3, 4,6-トリアセチル-D-グルコピラノシド (N) のニトロ化抢よび奥素化について検討し, から 1 種のクロラムフ

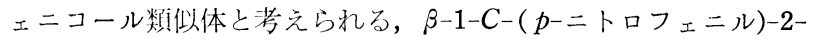
ジクルアセトアミノ-2-デオキシーD-グルコピラノシドを命成 し，その抗菌性を調べた。

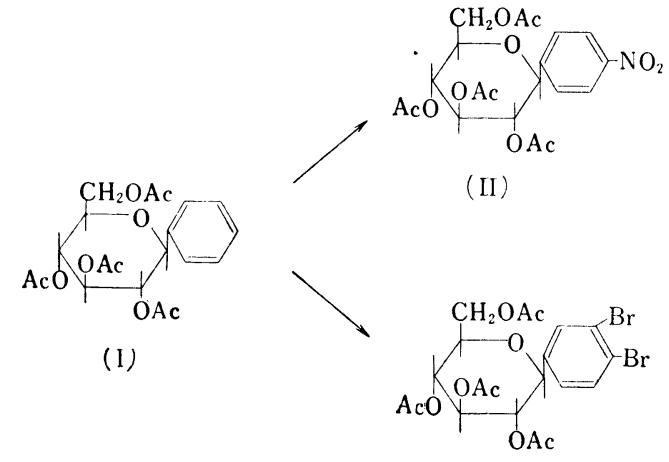

(III)
1) J. M. Craig, W. A. Bonner, J. Am. Chem. Soc. 72, 4808 (1950).

2) C. D. Hurd, W. A. Bonner, ibid. 67, 1764 (1945).

3) 日化 79, 1503 (1958); 80, 1472(1959).

\section{2 本交および結果}

化含物 IV 3 種の方法 [(i) 通常の混酸，（ii）無水酶酸抢よび 発煙硝酸，（iii）無水酢酸，酢酸打よび硝酸銅をとれぞれ用いる 方法]でニトロ化し, 生成物を酢酸エチルから分別結晶したとこ ろ, いずれの方法でも $p$-ニト口誘導体 (V) $\mathrm{mp} 278^{\circ} \sim 282^{\circ} \mathrm{C}$, $[\alpha]_{\mathrm{D}}^{23}=-49^{\circ}$ および $m$-ニト口誘導体 (VI), $\mathrm{mp} 234^{\circ} \sim 236^{\circ} \mathrm{C}$, $[\alpha]_{\mathrm{D}}^{20}=-59.5^{\circ}$ が得られた。(i) の方法で注，V抢よびVの収率 法それぞれ $53 \%$ および $15 \%$ で，炎れらを過マンガン酸カリウ ムで処理するとそれぞれ $p$-ニト口安息香酸, および $m$-ニト口 安息香酸が得られる。VおよびVを除いた残りの結晶（X), mp $216^{\circ} \sim 230^{\circ} \mathrm{C}$ を同様に処理すると， $p$-および $m$-ニト口安息香 酸が得られるが， 0 -ニトロ安息香酸と思われる生成物はみいだせ なかった。

また化合物（IV）溴素のみでは臭素化されずに約 $80 \%$ の未 反応物を回収したが,触媒として塭化第二鉄をもちい, 反応生成物 をアルコールから再結晶したところ， $p$-ブロム誘導体 (VII), $\mathrm{mp}$ $274^{\circ} \sim 276^{\circ} \mathrm{C},[\alpha]_{\mathrm{D}}^{20}=-50^{\circ}$ が約 $35 \%$ の収率で得られた。叫を 過マンガン酸カリウムで処理すると $p$-ブロム安息香酸が得られ る。UIIを口別した残りの母液を濃縮して得られる低融点の結晶を 同様に処理したところ, 大量の $p$-ブロム安息香酸とごく少量の

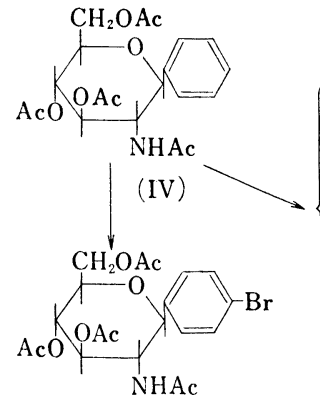

(VII)

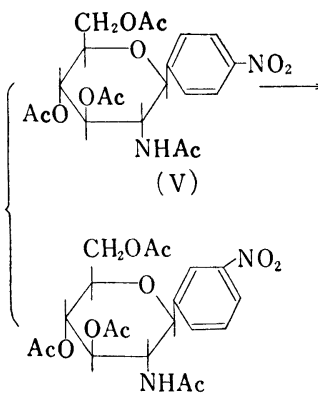

(VI)

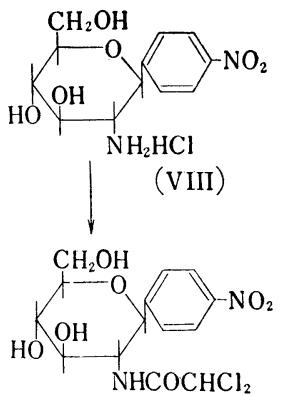

(IX)

mーブロム安息香酸が 得られ， 0 -ブロム安息香酸の存在はみいだ せなかった。

著者らはまた Bonner らやが行なったIのニトロ化を追試した 
ところ, 通常の混酸を用いても, 無水酶酸と発煙硝酸を用いても, 反応生成物をベンゼンーエーテルで处理すると容易に $p$-ニト口誘 導体（II）が分離されることをみいだした。また Bonner らは IIを分嗺した母液を濃縮して得られるシロップ（XI）の旋光度が II とはなはだしく相違すること，およびそれを過マンガン酸カりウ ムで处理すると大量の $p$-二トロ安息香酸と少量の $o$-二トロ安息 香酸が得られるが，その絶刘量が少ないととから，かなりの分解 が抢こっていると考光ている。著者らはこのシロップをマグネソ ル・セライト（5:1）のカラムにかけて二つにわけて为たが，旋 光度はあまり変化せず，いずれも結晶しなかった。しかし，その 分析值はいずれも純粋なモノニト口置換体のそれと亦まり相違し ていなかった（計算值 $\mathrm{C}_{20} \mathrm{H}_{23} \mathrm{O}_{11} \mathrm{~N}$ とて，C $52.98 \%, \mathrm{H}$ 5.11, N 3.09 亿対してそれぞれ実測值 C 54.60，53.80，H 5.06,

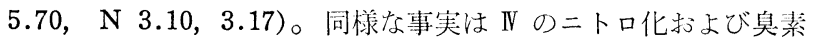
化の際に純粋な生成物堂除いた残りの結晶（前者法比旋光度約

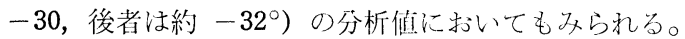

一般に糖残基がベンゼン核に炭素-孷素絬合で結合している誘 導体の吸收はトルエンのそ机に類似すると考光られる4)。そこで ここに得られた核置換反心生成物の構造をたしかめるために，そ の紫外線吸收を測定した。その結果を，相当する簡単なベンゼン 誘尊体の吸收ととも图 1 , 表 1 , 四 2 , 表 2 亿示した。またこ れらの赤外線吸収スペクトルを罒 3 にまとめて示した。

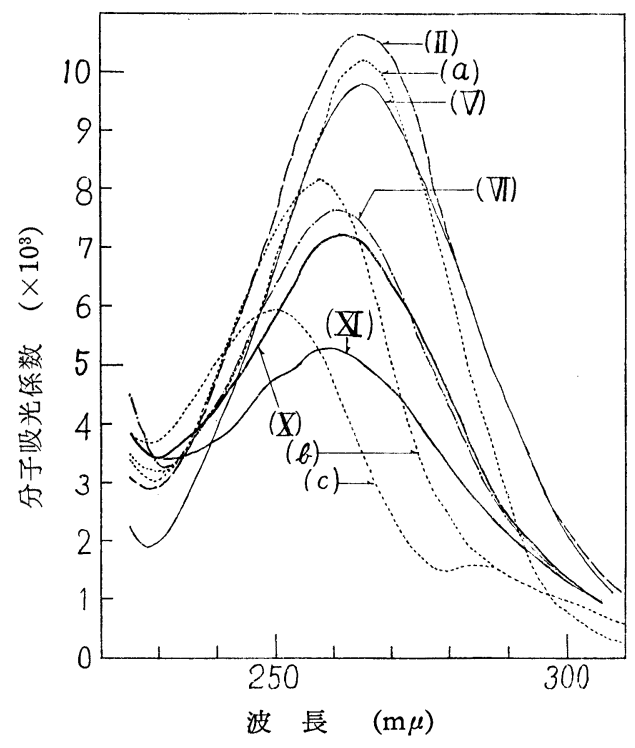

図 1 ニトロ誘導体の吸収曲線

表 1 ニト口誘導体の吸収（溶媒はメタノール）

$\begin{array}{lcc}\text { 化合物 } & \begin{array}{c}\lambda_{\max } \\ (\mathrm{m} \mu)\end{array} & \begin{array}{c}\text { 分子吸光係数 } \\ \left(\times 10^{3}\right)\end{array} \\ (\mathrm{a})^{5)} & 264 & 10.25 \\ (\mathrm{II}) & 264 & 10.6 \\ (\mathrm{~V}) & 265 & 9.78 \\ (\mathrm{~b})^{5)} & 256.5 & 8.16 \\ (\mathrm{VI}) & 260.5 & 7.63 \\ (\mathrm{X}) & 261.5 & 6.81 \\ (\mathrm{XII}) & 259 & 5.27 \\ (\mathrm{c})^{5)} & 250,285 & 5.95,1.65\end{array}$

注 (a), (b), (c) はそれぞれ $p^{-}, m-, o^{-}$ニトロトルエン.

4) M. C. Rebstock, et al., J. Am Chem. Soc. 71, 2458 (1949).

5) W. G. Brown, et al., ibid. 69, 1032 (1947).

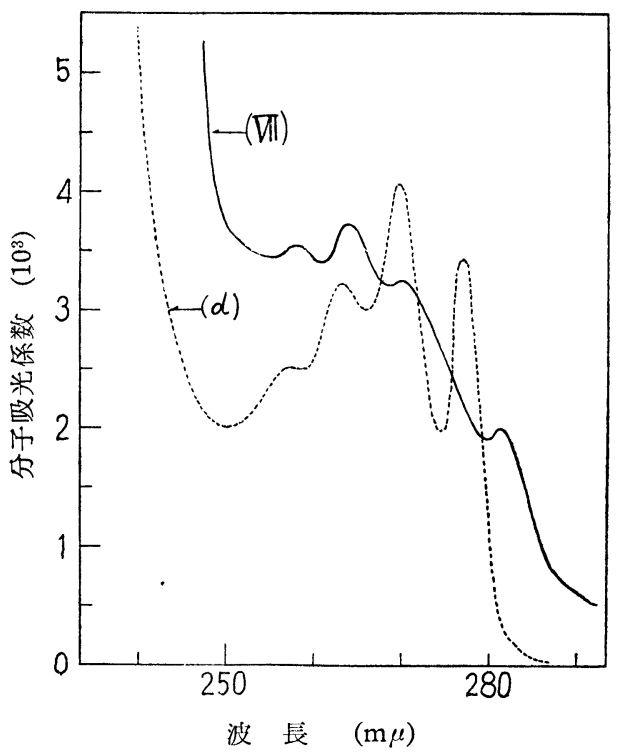

図 2 ブロム誘導体の收収曲線

表 2 ブロム誘導体の收収（浴媒はメタノール）

化合物 $\lambda_{\max }(\mathrm{m} \mu)$ 分子吸光係数 $\left(\times 10^{-2}\right)$

(d) $257,263,271,277 \quad 2.50,3.22,4.07,3.43$

(VII) $258,264,270,2813.55,3.73,3.25,2.00$

注

(d) は $p$-ブロムトルエン.

一方，化合物（V）の糖残基の炭素 1-位打よび 2-位の立体配 置は D-エリトロ系に属与ると考光られるが，これをクロラムフ ェニコール（D-トレオ-1-パラニトロフェニル-2-ジクロルアセト アミノプロパンジオール）のそれと比較してみると，両者の間に は興味ある関連性がタいだせる。そこでわれわれ汇化合物 V の $N$-ジクロルアセチル誘導体を合成し，その抗菌性の有無を調べ た。

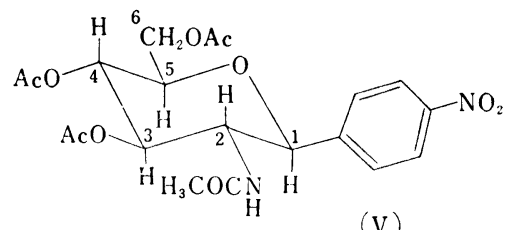

( V)<smiles>O=C(Cl)C(CO)C(O)c1ccc([N+](=O)[O-])cc1</smiles>

フロラムフェニコール

$\mathrm{V}$ を $50 \%$ アルコールの $1 \mathrm{~N}$ 盐酸中で約 3 時泪晹浴上で還流

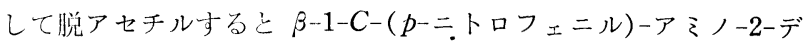
オキシーD-グルコピラノシド塩酸嫶 (VIII) $\mathrm{mp} 242^{\circ} \sim 244^{\circ} \mathrm{C}$ (分解) が吸湿性の白色結晶として得られる。ついで四のシロップあるい は結晶をブチルアルコールに溶解し, 過剩のジクロル酢酸メチル

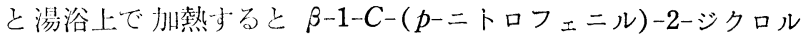

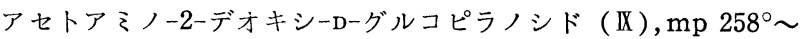
$259^{\circ} \mathrm{C},[\alpha]_{\mathrm{D}}^{27}=-6^{\circ}$ が得られる。 $\mathrm{X}$ の濃度 $200 \mathrm{mcg} / \mathrm{ml}$ まで の溶液について，その抗菌性をつぎの菌に対して調べたが，菌の 発育は阻止しなかった。 


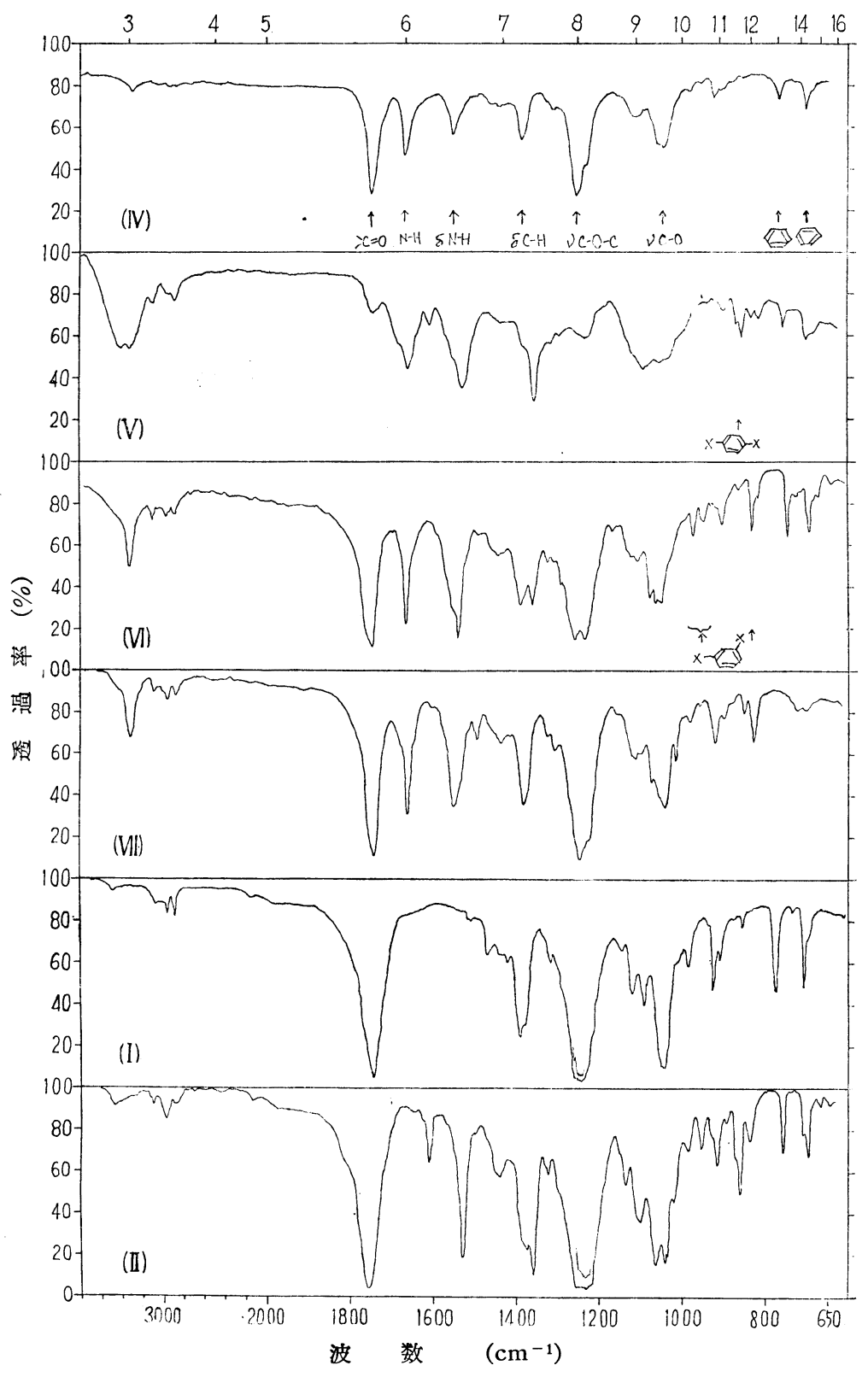

図３グリコシル誘導体の赤外線吸収曲線*1 $m$-置換体のそれに一致している。一方 X および 】の紫外吸収には， 0 -ニトロトルエンの特徵であ る $285 \mathrm{~m} \mu$ の吸収極大がみられず，前者の分子吸 光係数は大きい。また X を過マンガン酸カリウム で処理しても $\boldsymbol{O}^{-}$ニトロ安息香酸が得られなかっ た事実から，もし 0 -誘導体が生成するとしてもき わ出て少量であるうと考えられる。

図 2 に示されたように，化合物（VII）の吸収極 大および分子吸光係数は $p$-ブロム安息香酸のそ れに相当した值を示している。

以上，糖残基をメチル基に扮きかえて吸収を比 較検討したが，本研究でおこなった核置換反心で も糖残基はメチル基のようなオルト・パラ配位と 考えられる。七かし，実験結果からオルト誘導 体のかわりにメタ誘導体が得られることがわかっ た。ベンゼン核に刘するピラノシド環の配位傾向 については知られていないが，この結果からアル キル基のような弱いオルト・パラ配位がピラノシ ド環内の酸祘の感応効果によってさらに弱めら れ，ハロゲノメチル基に近くなっていると推論さ れる。

また,ジフェニルは $2,2^{\prime}$ 位に大きな置換基 (二 トロ基，カルボキシル基，アルコキシル基など）

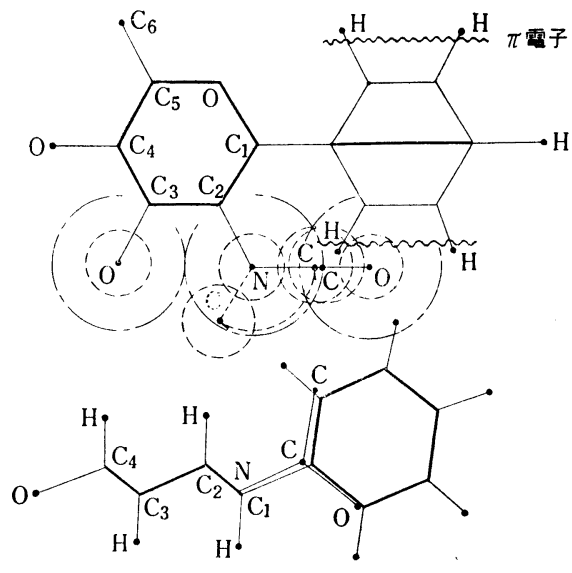

-..--原子半径 —-_- ファン・デル・ワールス半径
Escherichia coli Kauffmann O-1, Proteus vulgalis, Pseudomonas aeruginosa, Klebsiella pneumonia, PCI 601, Salmonella cholerae-suis S34, Salmonella enteritidis S64, Shigella flexneri 2a 1675, Shigella boydii 670 ,

Shigella sonnei II 37148, Staphylococcus aureus Terajima, Staphylococcus aureus FDA 209P, Staphylococcus citreus 以上 12 種類。

\section{3 考察}

四 1 にみられるように 大が $p$-ニトロトルェンに酷似しており，VI $m$-ニトロトルエ

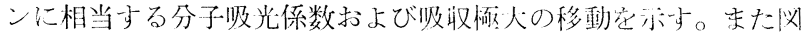
3 の Vおよび、の吸収にみられるように，810〜 800, $1165 \mathrm{~cm}^{-1}$ の領域に扮ける赤外吸収は，一般に涊められていろ6)，p-抢上び

*1测定は岩㙁プリズム，Perkin Elmer 分光器を用いた．
が導入されると新たに分子不斉が生ずることが知られている7。 グリコシル誘導体はジフェニルと異なりピラノシド環とベンゼン 核の閒の炭素-炭素結合が上図のようにピラノシド環の平面に対 して約 $20^{\circ}$ 傾斜しているが，ジフェニルの場合と同様に糖の炭 素 2 位のアセトア乏ノ基の立体障害によって, ベンゼン核はピラ ノシド環に対して直交に近い配置をとると考えられる。したがっ て，アセトアミノ基は容易にベンゼン核のオルト位を遮蔽するこ とができ，それによってオルト位における置換反応を妨害してい ると推論される。このようにしで新らしい分子不斉が生ずるとす れば，o-抢よび $m$-モノ置換体には 2 種の立体異性体が存在しう るわけであるが，XおよびXの旋光度が純䊉な誘導体のそれと違 っているにもかかわらず，それらの分析值が純粋な唀導体のそれ

6) L. J. Bellamy, “The Infrared Spectra of Complex Molecules" p. 81 (1958) London.

7) W. J. Hickinbottom, "Chemistry of Carbon Compounds" Vol III, p. 1031 (1956). 
に近い值它示すことはこれを暗示するように考えられる。

化合物（I）と（IN）核糖残基の炭素 2 位の置換基が相違する の夕で，核置換反応に対する影響はほとえど同じであると思われ る。しかし，前者からの生成物が結晶しにくいため詳細に調べる ことができなかったので，実験結果の相違についてはここではふ れない。

\section{4 実 験 の 部}

$4.1 \boldsymbol{\beta}-1-\boldsymbol{C}$-フェニル-2-アセトアミノ-2-デオキシ-3, 4, 6-ト リーアセチル-D-グルコピラノシド（IV）のニトロ化

（i） $15 \mathrm{cc}$ の濃硫酸（此重 1.8） と $15 \mathrm{cc}$ の濃硝酸（比重 1.38）からなる混酸を氷と食塩で冷却し，乙れに $3 \mathrm{~g}$ の化合物 $\mathrm{IV}$ を加えてかきまぜるとすぐに溶解する。約 30 分後, 水浴に变え 約 1 時間，ついで室温で 15 分間反応させる。反応液に約 $50 \mathrm{cc}$ の乾燥クロロホルムを加え, 計算量（約 $42 \mathrm{~g}$ ）の炭酸ナトリウ ムを懸濁した水水中に少しずつあけて中和する。水層とク口ロ ホルム層を分離し，水層はクロロホルムで 3 回抽出する。抽出液 をあわせて少量の飽和炭酸水素ナトリウム水溶液で 1 回，水で 3 回洗浄後, 無水ボウ硝で乾燥し, 減王濃縮すると約 $3.4 \mathrm{~g}$ の粗結 晶をうる。少量のエタノールで洗浄すると，わずかの着色物が除 去される。このようにして得られた粗結晶注融点が $228^{\circ} \sim 232^{\circ} \mathrm{C}$ であるが，適量の酢酸エチルから徐々に結晶を析出させると，最 初に綿のような繊維状結晶が析出する。これは $p$-ニト口綉導体 (V) で $\mathrm{mp} 278^{\circ} \sim 282^{\circ} \mathrm{C}, \quad[\alpha]_{\mathrm{D}}^{23}=-49^{\circ}$ （クロロホルム, $c=$ $0.9)$ 。

$$
\begin{aligned}
& \text { 分析值 C } 52.79 \%, \mathrm{H} 5.73 \% ， \mathrm{~N} 6.12 \% \\
& \mathrm{C}_{20} \mathrm{H}_{24} \mathrm{O}_{10} \mathrm{~N}_{2} \text { としての }
\end{aligned}
$$

計算值 C $53.09 \%, \mathrm{H} 5.35 \% ， \mathrm{~N} 6.19 \%$

p-ニトロ誘導体を除いていくか，酶酸エチルまたはエタノ一 ルで分別結晶をくり返していくと， $\mathrm{mp} 234^{\circ} \sim 236^{\circ} \mathrm{C},[\alpha]_{\mathrm{D}}^{20}=$ $-59.5^{\circ}$ (クロロホルム $c=0.97$ ) の $m$-ニトロ誘導体 (VI) を 針状結晶として分離することができる。

分析值 C $52.85 \%, \mathrm{H} 5.47 \%, \mathrm{~N} 6.44 \%$

$\mathrm{C}_{20} \mathrm{H}_{24} \mathrm{O}_{10} \mathrm{~N}_{2}$ としての

計算值 C $53.09 \%, \mathrm{H} 5.35 \%, \mathrm{~N} 6.19 \%$ これらの収量はVが $1.7 \mathrm{~g}(53 \%)$ ，Vが $0.5 \mathrm{~g}(15 \%)$ であった。 Vおよび Uをアルカリ性過マンガン酸カリウム溶液で加熱酸化分 解すると，それぞれ $p$ - 抢よび $m$-ニトロ安息香酸を与え，別に 合成したサンプルと混融しても融点の降下は両者とも示さなかっ た。

（ii） $1 \mathrm{~g}$ の化合物（IV）を $5 \mathrm{cc}$ の無水酶酸に溶解した溶液を $-15^{\circ} \mathrm{C}$ に冷却し，かきまぜながら $5 \mathrm{cc}$ の無水酰酸と $3 \mathrm{cc}$ の発 煙硝酸（比重 1.5）の混合物を加える。反応液は氷冷して 3 時間 かきまぜる。(i) と同様にあと処理し, 約 $380 \mathrm{mg}$ の化合物 (V) (35\% 理論量) および約 $70 \mathrm{mg}$ (6.3\% 理論量) の化合物 (V) が得られる。

(iii） $0.5 \mathrm{~g}$ の化合物（N) をもちい，Bonner らの方法1)にし たがって処理して約 $90 \mathrm{mg}$ (17\% 理諭量) の化合物 (V) と約 $30 \mathrm{mg}$ (5.4\%理論量) の化合物Vをを得た。

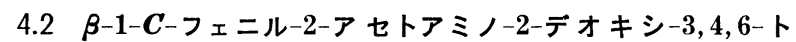
リーアセチル-D-グルコピラノシド (IV) の臭素化

$2.5 \mathrm{~g}$ の化合物 $\mathrm{N}$ と $0.3 \mathrm{~g}$ の塩化第二鉄と $20 \mathrm{cc}$ の臭素々の混 合物を，ときどきふりまぜながら約 4 時間室温で放置する。IV は ほとえど溶解するが壏化第二鉄は大部分が懸濁している。過剩の 臬素注減在吸引して除き, 残分をクロロホルムに溶解与る。クロ ロホルム溶液を少量の酸性雨硫酸ナトリウム水溶液掞よび水で洗

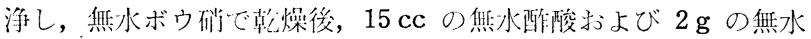

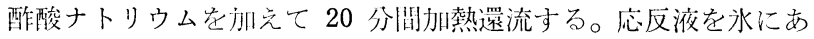
け，過剩の舤水酷骖范分解したのちクロロホルム抽出を抢こない， 抽出液は飽和炭酸水素ナトリウム溶液打よび水で洗浄後, 乾燥・ 減庄浱縮する。残分をエタ人ールあるいは酢酸エチルから再結晶 すると約 $0.8 \mathrm{~g}(27 \%)$ の $p$-ブロム誘導体（VII)， mp $274^{\circ}$ $276^{\circ} \mathrm{C},[\alpha]_{\mathrm{D}}^{20}=-50^{\circ}(c=0.48$, クロロホルム) が得られる。 分析值 $\mathrm{C} 48.90 \%, \mathrm{H} 5.04 \%, \mathrm{~N} 2.89 \%, \mathrm{Br} 16.25 \%$

$\mathrm{C}_{20} \mathrm{H}_{24} \mathrm{O}_{8} \mathrm{NBr}$ としての

棓算值 C $49.39 \%, \mathrm{H} 4.97 \%, \mathrm{~N} 2.88 \%, \mathrm{Br} 16.43 \%$ これをアルカリ性過マンガン陵カリウムで酸化すると $p$-ブロム 安息香酸（mp $246^{\circ} \sim 247^{\circ} \mathrm{C}$ ) が得られ，別に合成したサンプル $\left(\mathrm{mp} 251^{\circ} \sim 253^{\circ} \mathrm{C}\right)$ と混融したが融点の降下（mp 248 〜 252 C ）を宗さなかった。

\section{$4.3 \boldsymbol{\beta}-1-\boldsymbol{C}-(\boldsymbol{p}-$ ニトロフェニル $)-2-\boldsymbol{ー}$ ミノ -2-デオキシ-D-グ ルコピラノシド塩酸塩 (VIII)}

$0.5 \mathrm{~g}$ の化合物 $\mathrm{V}$ を $50 \%$ のアルコールの $1 \mathrm{~N}$ 塩酸 $16 \mathrm{cc}$ に 溶解し，3 時䦎湯浴上で還流する。応反液を減压濃縮し，残りの シロップをエタノールに溶解し，わずかに白濁が起るまで石油エ 一テルを加えて, 冷蔵㡹中に放䈯すると白色針状絬昆が析出する。 収量約 $0.1 \mathrm{~g}$ ( $34 \%$ 理論量), $\mathrm{mp} 242^{\circ} \sim 244^{\circ} \mathrm{C}$ (分解)。

分析值 C $44.37 \%, \mathrm{H} 5.45 \%, \mathrm{~N} 8.05 \%, \mathrm{Cl} 10.72 \%$

$\mathrm{C}_{12} \mathrm{H}_{16} \mathrm{O}_{6} \mathrm{~N}_{2} \cdot \mathrm{HCl}$ としての

計算优 C $44.93 \%, \mathrm{H} 5.34 \% ， \mathrm{~N} 8.74 \%, \mathrm{Cl} 11.05 \%$ この化合物は吸湿性が強く, 結晶し難い。4 回実験を行なった が 1 回しか結晶が得られなかった。

$4.4 \boldsymbol{\beta}-1-\boldsymbol{C}-(\boldsymbol{p}-$ ニトロフェニル $)-2-$-ジクロルアセトアミノ-2デキシ-D-グルコピラノシド $(\mathbf{I X})$

$0.5 \mathrm{~g}$ の Vよりつくった化合物（VIII）のシロップをデシケータ 一中で乾燥し， $4 \mathrm{cc}$ の $n$-ブタノールに溶解し, 計算量 $(0.021$ g）の金属ナトリウムを加えて中和する。それに $1 \mathrm{cc}$ のジク口 ル酶酸メチルを加え 5 洔間加熱還流する。冷却後, 応反液を減圧 濃縮し，残分をアルコールから 1 回，水から 1 回，それぞれ再結 晶すると白色針状結晶をうる。収量 $0.2 \mathrm{~g}$ ( Vから $45 \%$ 理論量), $\mathrm{mp} 258^{\circ} \sim 259^{\circ} \mathrm{C},[\alpha]_{\mathrm{D}}^{27}=-6^{\circ}$ (エタノール, $c=0.8$ )。

分析值 C $42.61 \%, \mathrm{H} 4.61 \%, \mathrm{~N} 7.40 \%, \mathrm{Cl} 17.72 \%$ $\mathrm{C}_{14} \mathrm{H}_{16} \mathrm{O}_{7} \mathrm{~N}_{2} \mathrm{Cl}_{2}$ としての

計算值 C $42.52 \%, \mathrm{H} 4.08 \%, \mathrm{~N} 7.09 \%, \mathrm{Cl} 17.94 \%$ 終りに，抗菌性試験をして下さった山之内製薬株式会社試験室 のかたがた，元素分析をして下さった当有機化学教室分析室のか たがたに深く感謝する。

（1958 年 9 月，日本化学会東北地方大会（一部）講演） 